Berlin stands to lose out on DM19 million in federal money if it refuses to cofinance the successor programme. "It is disgraceful," says Seifert, adding that during the three years of the special university programme, Berlin WIPianers won DM20 million in grant money.

The programme cost Berlin DM25 million, which was matched by federal funds. "Every mark paid by the city was converted to nearly three marks for research in Berlin," Seifert says.

But the average age of the remaining WIPianers is increasing and many fear that the excuse of impending retirement will be used to deal with the problem. Joachim Sobotka, a 62-year-old agricultural ecologist, says that if he is forced to retire early because his funds are discontinued, it will mean unemployment for the research team he has built up at Humboldt University, which has published 25 papers in the past few years.

Most Berlin WIPianers are unwilling to comment publicly on their plight, fearing that it could further jeopardize their employment prospects. But they plan to lobby Berlin's parliamentarians individually to ask them to vote against the science ministry's plans to withdraw from the new programme.

http://www.gew-berlin.de/wip/chronik1.htm

\title{
German government takes a narrow view of gene patents
}

\section{Quirin Schiermeier, Munich}

Germany's research minister Edelgard Bulmahn promised last week that new legislation on patents on genetic material would specify that they should be given a narrow interpretation.

The pledge came at a meeting attended by Bulmahn and the minister for legal affairs, Herta Däubler-Gmelin, as well as academics, industrialists and patent experts. The meeting discussed changes to Germany's patent laws that are to bring them in line with the European directive on the legal protection of biotechnology.

The commitment to the new legislation - which should have been approved by the end of last month - was welcomed by representatives from the biotechnology industry. "Harmonized European patent rules will give us the legal security we need," says Thomas von Rüden, chief scientific officer of the Munich-based company MorphoSys.

But there was also agreement at the meeting that patents issued should be interpreted in a "narrow way". This reflects concerns expressed last month by German scientists that broad gene patents could hinder the

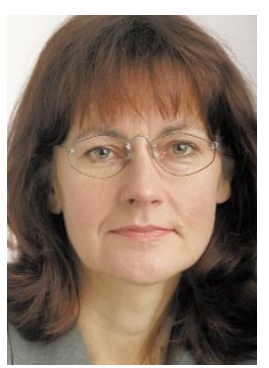

exploitation of newly discovered functions for DNA sequences (see Nature 406, 111; 2000).

Bulmahn said that the legal comments that would accompany the directive should encourage a 'researchBulmahn: wants laws friendly' interpreta-
friendly to research.

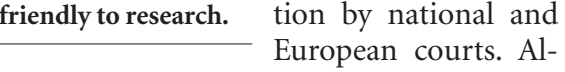
though not legally binding, these comments are aimed at guiding the interpretation of a law by the courts.

Some scientists oppose the idea that patents involving genetic information should get special treatment, believing that patents should be seen as incentives, rather than obstacles, to researchers.

But Detlev Ganten, scientific director of the Berlin-based Max Delbrück Center for Molecular Medicine, questions whether Bulmahn's concession goes far enough. "Gene patents should, on principle, be restricted to identified functions," he says.

\section{Deal on reprints could mean royalties for scientists}

\section{Rex Dalton, San Diego}

Many published scientists could be eligible for a share in a $\$ 7.25$ million settlement resulting from a federal lawsuit in Oakland, California. Approved by the US District Court late last month, the fund will compensate authors who have had reprints of published articles sold without their consent.

The class action lawsuit was launched two years ago when five authors sued UnCover, a document delivery firm based in Denver, Colorado, claiming that they had been cheated of royalty payments. Although the original plaintiffs were freelance writers and journalists, scientists are among the potential beneficiaries, as many of the articles distributed by UnCover were from scientific journals.

The compensation could be worth as much as $\$ 30,000$ per document delivery. But the actual amount will depend on the number of authors who successfully file claims, and may not be so high.

Any author who retained the rights to their work after initial publication is eligible to apply for compensation. Three-quarters of the settlement fund, less the estimated

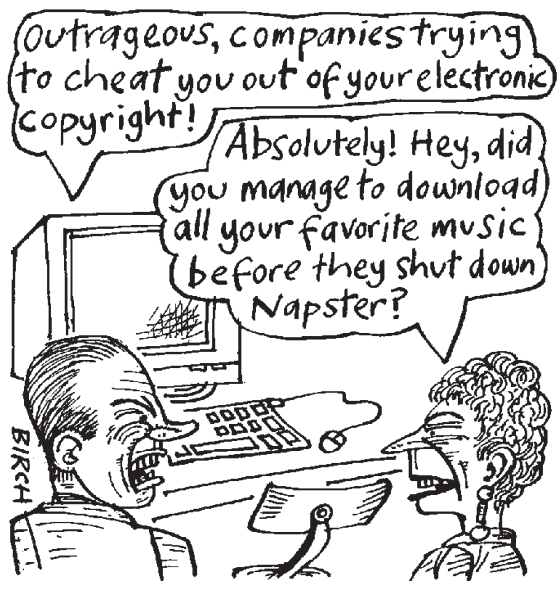

$\$ 3$ million in legal costs for the plaintiffs' attorneys, has been set aside for such claims. The remaining quarter will go to authors who did not register their US copyright, but retained the right after first publication.

"Selling individual articles electronically without authors' permission has been an industry-wide practice," says John Shuff, one of the authors' attorneys. He expects the case to have a significant impact on the burgeoning world of Internet publishing.
In some cases, UnCover had made arrangements to secure rights from publishers to distribute documents. But it had not always reached agreement with the authors. As part of the settlement, UnCover - now owned by the British firm Ingenta has agreed to seek the permission of authors and pay royalties in the future.

Robert Eisenbach, an attorney representing UnCover and Knight-Ridder, a previous owner of the company, said the settlement was reached to avoid future litigation costs.

Some observers believe that the agreement might hinder the distribution of scientific literature. Stevan Harnad, a professor of cognitive sciences at the University of Southampton in England, calls it "nothing but short-sighted nonsense". Others feel scientists are entitled to be paid for their work, just like any other author.

It is uncertain how many scientists are eligible for compensation because of the different arrangements between authors and publishers. Authors can check on the web whether UnCover distributed their articles. Claims must be filed by 27 October 2000 . http: //www.uncoversettlement.com 